\title{
How Different are FDI and FPI Flows?: Distance and Capital Market Integration
}

\author{
Rabin Hattari \\ Asian Development Bank \\ Ramkishen S. Rajan \\ George Mason University
}

\begin{abstract}
The availability of bilateral capital flows between countries has given rise to a number of papers attempting to understand trends and determinants of capital flows between country pairs. Almost without exception, the papers find that the gravity model fits the data quite well. Specifically, while economic sizes of the host and source (measured by GDP, population etc) appear to positively impact bilateral flows in most cases, distance -- broadly proxying some sort of transactions and / or information frictions -- stands out as consistently hindering all types of capital flows. But does greater distance hinder both foreign portfolio investment (FPI) and foreign direct investment (FDI) flows equally? In other words, does distance change the composition of capital flows? This is the specific question that this paper focuses on, differentiating between total FDI, FDI via mergers and acquisitions (M\&As) and FPI.
\end{abstract}

-JEL Classification: F21, F21, F23

- Keywords: Distance, Foreign Direct Investment (FDI), Foreign Portfolio Investment (FPI), Gravity, Mergers and Acquisitions (M\&As)

\footnotetext{
*Corresponding address: Rabin Hattari: Public Management Economist, Financial Setor, Public Management and Trade Division, Southeast Asia Department, 6 ADB Avenue, Mandaluyong City, 1550 Metro Manil, USA, Tel: 632632 4444, Fax: 632636 2444, E-mail: rhattari@adb.org. / Ramkishen S. Rajan: Public Policy and International Economic Policy School of Policy, George Mason University, 3351 Fairfax Drive, 3B1 Arlington, VA22201, USA, Tel: +1 704993 3700, Fax: +1 708851 4233, Email: rrajan1@gmu.edu.

@2011-Center for Economic Integration, Sejong Institution, Sejong University, All Rights Reserved.
} 


\section{Introduction}

Openness to cross-border capital flows is a double-edged sword. On the one hand, greater capital inflows facilitate growth by supplementing domestic resources and bringing in new technological know-how. On the other hand, capital inflow surges and sudden stops and reversals are the proximate causes of many financial crises that have plagued many emerging economies since the 1990s. Given its importance, there has understandably been a burgeoning literature dealing with the determinants of cross-border capital flows. While the early literature which was limited to using aggregate country data focused on "push" and "pull" factors (for instance, see Calvo, Leiderman and Reinhart, 1996 and Dasgupta and Ratha, 2000), the availability of data on bilateral capital flows between countries has motivated a voluminous literature attempting to understand the trends and determinants of capital flows between country pairs. Drawing on the more established trade literature (see Coe et al., 2007; Deardorff, 1996; Evenett and Keller, 2002; Feenstra et al., 2002; Helpman et al., 2008 and Grossman, 1996), most of the papers apply some version of the gravity model to various types of international capital flows.

For instance, in the case of foreign direct investment (FDI), Stein and Daude (2007) investigates the effects of time zone differences on bilateral stocks of FDI for 17 OECD source countries and 58 host countries over the period 1997-1999, estimating a gravity model using both OLS and Tobit specifications. Hattari and Rajan (2008) estimates a gravity model to investigate the determinants of bilateral FDI flows to developing Asia from sources within and outside the region using a panel comprising 24 source countries and 12 host countries for the period 19902005. Hattari and Rajan (2009a) examines the determinants of intra-Asian bilateral FDI flows for selected 14 developing countries in Asia over the period 1990-2005. Rajan and Hattari (2009) uses the same database to examine the role of information asymmetries measured by telephone traffic on intra-Asian FDI flows. All these papers use the two-stage Tobit procedure. Talamo (2007) explores the determinants of FDI flows from industrialized OECD countries to 61 host countries (comprising both OECD and non-OECD countries) by estimating a fixed effects OLS gravity model on a panel over the period 1980-2001. Wei (2000) is a cross-country study that examines the impact of corruption on FDI using bilateral investment data from 12 source countries and 45 host countries for 1993 by estimating a gravity model using quasi-fixed effect and Tobit procedures. Tong (2005) is a cross-country study that analyzes the role of ethnic Chinese networks/diasporas in facilitating bilateral 
FDI transactions by applying an OLS and threshold Tobit gravity estimation to a panel of bilateral FDI stocks among 71 economies for the period 1989-1991.

In the case of cross-border Mergers and Acquisitions (M\&As), Di Giovanni (2005) investigates their economic and financial determinants across 193 countries for the period 1990-1999. Hattari and Rajan (2009b) examine the financial drivers of cross-border M\&As using a panel comprising 53 source countries and 60 host countries for the period 2000 to 2007 . Wong (2008) is a cross-country study that investigates the goodness of fit of a gravity model on M\&A-flows in comparison to trade and telephone traffic flows for a sample of 193 countries for 1999. All these studies estimate their specifications using a two-stage Tobit procedure. Coeurdacier et al. (2009) apply a gravity model using a Poisson Maximum Likelihood Estimation (MLE) technique to examine the impact of joining the EU and Eurozone on M\&As on the members at the sectoral level (in manufacturing and services) over the period 1985-2004.

In the case of foreign portfolio transactions, the pioneering study has been done by Portes and Rey (2005) who apply a gravity model to a panel of bilateral gross crossborder portfolio equity flows between 14 countries for the time period 1989-1996. Lane and Ferretti (2008) is a cross-country study that investigates the determinants of bilateral portfolio equity holdings in 67 source countries and nearly 218 destination countries applying an OLS fixed effects and a Tobit type gravity model using data for the end of 2001. Lee (2008) examines the determinants of financial integration in East Asia by estimating a random effects gravity model for a panel of cross-border holdings of various financial assets (equity portfolio, long-term and short-term debt securities, and bank claims) between 2001 and 2003. ${ }^{1}$ Garcia-Herrero et al. (2009) analyze empirically the determinants of the composition of cross-border portfolio holdings (bond and equity flows) of 42 countries for the period 2001 to 2005 by estimating a gravity model using OLS random effects. Portes et al. (2001) estimate a pooled OLS gravity model for bilateral cross-border portfolio flows (covering different types of securities including corporate equities, corporate bonds and government bonds) between the US and a set of 50 advanced and emerging economies for the period 1988-1998.

Apart from equity and bond flows, others have applied the gravity model to sovereign debt flows (Rose and Spiegel, 2004), international bank lending and payments flows (Buch, 2005 and Papaioannou, 2009) and equity trading and market

${ }^{1}$ While the bilateral international portfolio asset holdings data used by Lee (2008) cover 223 destination countries, the international bank claims are gathered only for 25 destination countries. 
correlations (Flavin et al., 2002). ${ }^{2}$ Almost all the papers arrive at the conclusion that the gravity model fits the data quite well. Specifically, while economic sizes of the host and source (measured by GDP, population, market capitalization, etc) appear to positively impact bilateral flows in most cases, distance stands out as consistently hindering all types of capital flows. The persistence of the distance puzzle is fairly robust across different types of cross-border activities.

The distance elasticities (in absolute terms) vary depending on the types of capital flows, set of countries, time period, regression methodology, use of stocks versus flows, and types of controls used to augment the gravity model, with a mean and median elasticity of around 0.8 (Table 1). Given the finding of the importance of distance in hindering different types of capital flows, ${ }^{3}$ some studies have gone on to examine to what extent this distance variable is measuring informational gaps and asymmetries (for instance, see Loungani et al., 2002; Portes and Rey, 2005; Rajan and Hattari, 2009; Di Giovanni, 2005; Daude and Fratzscher, 2008, etc). ${ }^{4}$ Stein and Daude (2007) and Hattari and Rajan (2008) have suggested that differences in time zones may explain the persistence of distance elasticity.

An interesting question that arises is to what extent the gravity variables impact different types of capital flows differentially. This issue has not been examined systematically. In particular, does greater distance hinder all types of bilateral flows equally or are some types of flows more impacted than others? In other words, does distance affect the composition of cross-border equity flows? This is the question that is of focus here. Due to data availability, and consistent with the theory/ hypotheses to be laid out, we focus on equity flows only, limiting our attention to foreign portfolio (equity) flows (henceforth FPI) and FDI, and also differentiate between total FDI and FDI in the form of $M \& A s$ (the other type of FDI being the Greenfield variety).

The remainder of the paper is organized as follows. Section II briefly discusses the existing literature that deals with the composition of capital flows. Section III outlines the broad hypotheses to be tested. Section IV introduces the data and the empirical model. Section V discusses the results. Section VI concludes the paper.

\footnotetext{
${ }^{2}$ The review, while fairly comprehensive, does not claim to be exhaustive. Other studies have examined more specific questions such as whether China has diverted FDI from other Asian countries (for instance, see Eichengreen and Tong, 2007 and Liu et al., 2006).

${ }^{3}$ See Buch et al. (2004) for a discussion of interpretation of the distance coefficients in the gravity model. ${ }^{4}$ While not attempting to specifically tackle the distance puzzle, Javorcik et al., (2011) and Tong (2005) stress the role of diasporic networks in mitigating informational, cultural and other barriers to bilateral FDI. These networks could also serve as contract enforcement mechanisms.
} 
Table 1. Estimated Distance Elasticities

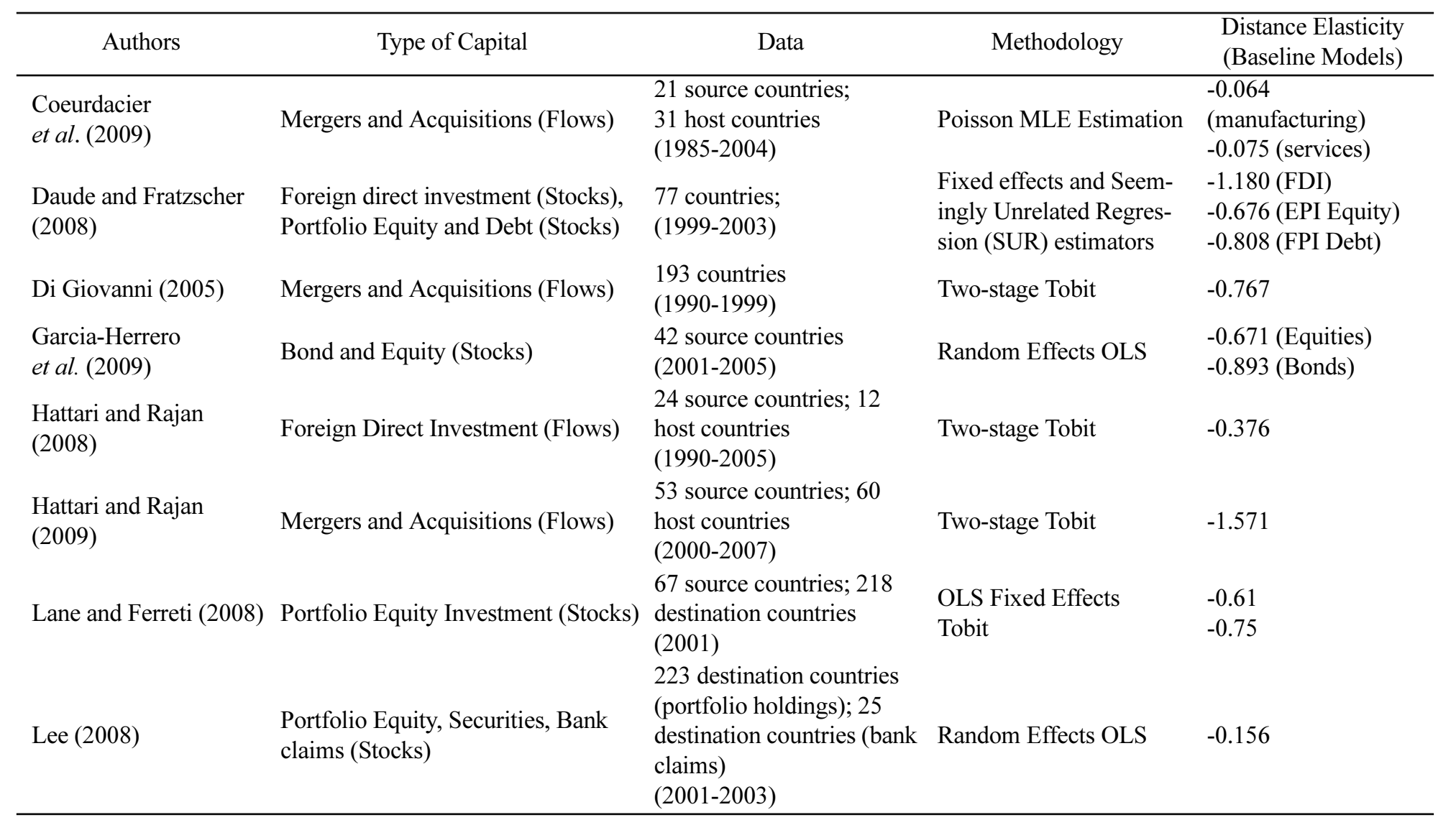


Table 1. Estimated Distance Elasticities (continued)

\begin{tabular}{|c|c|c|c|c|}
\hline Authors & Type of Capital & Data & Methodology & $\begin{array}{l}\text { Distance Elasticity } \\
\text { (Baseline Models) }\end{array}$ \\
\hline Portes and Rey (2005) & Portfolio Equity (Flows) & $\begin{array}{l}14 \text { countries } \\
(1989-1996)\end{array}$ & OLS & -0.881 \\
\hline Portes et al. (2001) & Portfolio Equity and Debt (Flows) & $\begin{array}{l}40 \text { countries } \\
(1988-1998)\end{array}$ & OLS & $\begin{array}{l}-0.601 \text { (Treasury bonds) } \\
-0.826 \text { (Corporate equities) } \\
-0.795 \text { (Foreign bonds) }\end{array}$ \\
\hline $\begin{array}{l}\text { Rajan and Hattari } \\
\text { (2009a) }\end{array}$ & Foreign Direct Investment (Flows) & $\begin{array}{l}14 \text { countries } \\
(1990-2005)\end{array}$ & Two-stage Tobit & -0.83 \\
\hline $\begin{array}{l}\text { Rajan and Hattari } \\
\text { (2009b) }\end{array}$ & Foreign Direct Investment (Flows) & $\begin{array}{l}14 \text { countries } \\
(1990-2005)\end{array}$ & Two-stage Tobit & -0.809 \\
\hline Stein and Daude (2007) & Foreign Direct Investment (Stocks) & $\begin{array}{l}17 \text { source countries; } 58 \\
\text { host countries } \\
(1997-1999)\end{array}$ & $\begin{array}{l}\text { OLS } \\
\text { Tobit }\end{array}$ & $\begin{array}{l}-0.957 \\
-1.551\end{array}$ \\
\hline Talamo (2007) & Foreign Direct Investment (Flows) & $\begin{array}{l}61 \text { host countries } \\
(1980-2001)\end{array}$ & Fixed Effects OLS & -0.603 \\
\hline Tong (2001) & Foreign Direct Investment (Stocks) & $\begin{array}{l}71 \text { countries } \\
(1989 ; 1990 ; 1991)\end{array}$ & $\begin{array}{l}\text { OLS } \\
\text { Threshold Tobit }\end{array}$ & $\begin{array}{l}-0.840 \text { (Inflows) } \\
-1.341 \text { (Outflows) } \\
-0.820 \text { (Inflows) } \\
-1.206 \text { (Outflows) }\end{array}$ \\
\hline Wei (2000) & Foreign Direct Investment (Stocks) & $\begin{array}{l}12 \text { source countries; } \\
45 \text { host countries } \\
(1993)\end{array}$ & $\begin{array}{l}\text { OLS Fixed Effects; } \\
\text { Modified Tobit }\end{array}$ & $\begin{array}{l}-0.60 \\
-0.29\end{array}$ \\
\hline Wong (2007) & $\begin{array}{l}\text { Trade(Flows), Telephone (Flows), } \\
\text { Mergers and Acquisitions (Flows) }\end{array}$ & $\begin{array}{l}193 \text { countries } \\
(1999)\end{array}$ & Two stage Tobit & $\begin{array}{l}-1.21 \text { (Trade) } \\
-1.04 \text { (Tel traffic) } \\
-0.48(\mathrm{M} \& \mathrm{~A})\end{array}$ \\
\hline
\end{tabular}




\section{Literature Review: FDI versus FPI}

The literature on composition of capital flows in general is quite limited. According to conventional wisdom, FDI and FPI flows are entirely different beasts. The former are considered to be relatively stable, driven by long-term fundamentals such as country size, financial market development, degree of openness, and the like. In contrast, the latter are viewed as being more volatile, highly reversible, and driven by cyclical factors, including interest rates differentials, business cycle conditions, market sentiments and herd behavior. Chuhan et al. (1996), Levchenko and Mauro (2006), Sarno and Taylor (1999), Sula and Willett (2006) and the World Bank (1999) are among a number of studies that find FDI flows to be relatively more stable than FPI. ${ }^{5}$ In addition, empirical analysis suggests that emerging economies most prone to currency crashes tend to have a relatively smaller share of FDI in total capital inflows. For instance, using a probit analysis, Frankel and Rose (1996) model the probability of a currency crisis as a function of the stock of FDI and nonFDI liabilities. Based on a set of over 100 emerging economies for the period 197192, they find that a low ratio of FDI to debt is linked to a greater likelihood of a currency crisis. $^{6}$ Tong and Wei (2009) argue that adverse liquidity shocks are more severe for countries that have been exposed to higher levels of FPI (and foreign loans) than FDI pre-crisis.

Thus, the popular belief is that FDI is a relatively safe form of external finance as it is "bolted down", while FPI is viewed as unstable, "hot money" and more prone to destabilizing the economy. This conventional wisdom has given rise to strong policy pronouncements such as -- a country should selectively liberalize capital account controls on FDI transactions while still maintaining or even tightening controls on

\footnotetext{
${ }^{5}$ Hausmann and Fernandez-Arias (2000) opine that countries with less developed financial markets and institutions - and are presumably more volatile - tend to attract inflows in the form of FDI rather than FPI. In other words, foreign investors are more likely to enter the country directly via FDI compared to other forms of capital flows when there are underdeveloped or inefficient markets and it may therefore be an indicator of some fundamental weaknesses of the host economy. Also see Daude and Fratzscher (2008). ${ }^{6}$ Hausmann and Fernandez-Arias (2000) confirm the Frankel-Rose result but show that it is not robust when extended to industrial countries. The authors note that these results may be because industrial countries have a much larger stock of non-FDI liabilities than do developing countries and have a lower frequency of crisis. Other empirical studies that have attempted to link the composition of capital flows to crises include Bussiere and Mulder (1999) and Niththanprapas and Willett (2000). In neither case is the result clear-cut. Theoretically, Goldstein et al. (2007) argue there may be reverse causality, i.e. when firms expect there to be greater volatility (or, more specifically, expect to be hit by negative liquidity shocks), they may prefer to undertake FPI rather than FDI as the former is considered easier to liquidate.
} 
FPI (and short-term debt) flows. ${ }^{7}$ In some senses, however, this conventional wisdom is rather curious. After all, a careful examination of the definition of FDI reveals it consists of three components, viz. new foreign equity flows, intra-company debt transactions and reinvested earnings. As a matter of convention, equity needs to involve only a $10 \%$ threshold value of ownership to be considered as FDI. This component in turn could take the form of either M\&As of existing local enterprises or Greenfield investments (i.e. establishment of new production facilities).

If FDI takes the form of Greenfield investments, one could reasonably argue that it is quite different from FPI flows. However, according to UNCTAD (2008), FDI has been rising in recent years, driven largely by M\&A flows. The share of M\&As to FDI rose from around 0.1 in 1992 to a high of almost 0.7 in 2000 before averaging around 0.4 thereafter (Figure 1). ${ }^{8}$ This is an important point. If a foreign entity undertakes a cross-border acquisition of less than $10 \%$, it is regarded as FPI flows. As an example, the Chinese sovereign wealth fund (SWF) originally purchased a $9.9 \%$ stake in the largest US private equity firm, Blackstone Group. Therefore, this investment enters the balance of payments as FPI flows from China to the US. If the Chinese had purchased a stake of above $10 \%$ stake, the transaction would have been categorized as FDI. ${ }^{9}$

Do small differences in equity ownership represent substantially different investment horizons? The IMF (1998) has similarly drawn attention to the fact that the distinction between FPI and FDI flows in the balance of payments can be arbitrary. Using annual data for selected emerging economies for 1991-98, Carlson and Hernández (2002) conclude that "portfolio equity flows respond to policies in a manner similar to that of FDI and in a manner opposite to that of short-term debt. It may be that portfolio equity is not of a short-term nature after all” (pp.23). A potential danger is that policy measures designed to encourage FDI may involve not

\footnotetext{
${ }^{7}$ Acharya et al. (2008) argue that negative correlations between FDI and FPI may occur if there is a firesale of assets during a crisis and foreign investors who have bought controlling equity stake then turn around and sell part of their stake following asset price revaluations, once the crisis abates. Also see Aguiar and Gopinath (2005).

${ }^{8}$ However, as will be discussed later, the comparison of FDI and M\&A is not straightforward.

${ }^{9}$ This and other investments by foreign SWFs in the US have tended in recent times to be less than $10 \%$ so that they are not categorized as FDI and therefore do not need to undergo the evaluation by Committee on Foreign Investment in the United States (CFIUS). See http://www.treas.gov/offices/ international-affairs/exon-florio/. Martin (2008) has also emphasized that there was a strategic reason behind China's decision to purchase something less than $10 \%$ of Blackstone's shares. As he notes, according to Blackstone's CEO and Chairman Stephen A. Schwarzman, "The deal is 'purely commercial' and do [sic] not need the U.S. government approval as the stake is less than $10 \%$ " (pp.8). The Chinese investment was later increased to a $12.5 \%$ stake.
} 
only a distortionary cost but also little gain in terms of enhanced financial stability. Given the growing interconnections between FDI and FPI there is clearly a need for more analysis of this issue at all levels. The remainder of the paper focuses on the specific issue of the role of distance and information on total FDI, FDI via M\&As and FPI (equity).

\section{FDI, FPI, and the Role of Distance}

To our knowledge, the only other paper that systematically compared the determinants of capital flows using bilateral data is Daude and Fratzscher (2008). However, they do not look at ratios (as we do). Instead they estimate a gravity model using the seemingly unrelated regression (SUR) methodology to understand the determinants of cross-border investments, covering FDI, portfolio equity securities and debt securities, for 77 countries over the period 1999-2003 (around 1160 observations). They do not focus on the type of FDI, i.e. M\&A versus Greenfield and use stocks as opposed to flows, as done in this paper (for the period 2000-2007).

Goldstein and Razin (2006) is one of the few papers that examines the determinants of FDI versus FPI in a theoretical framework. In their informationbased model, there is a fundamental tradeoff between sunk costs and liquidity. On the one hand, FDI ought to offer greater returns as it allows for more ownership and control and presumably is managed more efficiently than FPI in which management is delegated to outside parties. The problem with FDI, on the other hand, is that it involves significant upfront costs and much higher transactions costs unlike FPI which is a "weightless asset" and therefore is more liquid. A priori, insofar as greater distance is associated with informational asymmetries and unfamiliarity (thus raising the risk of adverse negative shocks) it ought to hinder FDI relatively more than FPI. However, there are some important caveats to this conclusion.

First, it is important to distinguish between horizontal and vertical FDI. Horizontal FDI usually occurs when the multinational undertakes the same production and related activities in multiple countries. A firm can service a foreign market either by exporting or by establishing a presence overseas (i.e. FDI). Insofar as greater distance implies higher transport costs which increases the cost of servicing the market via exports, this could motivate greater FDI, if these trade costs exceed the sunk costs of establishing presence overseas (Markusen, 1984). Vertical FDI, on the other hand, occurs when the multinational undertakes different parts of the production process in different countries. This in turn suggests that greater distance 
may discourage such FDI as it raises transaction costs. FPI equity, on the other hand, is a largely uniform type of investment. Thus, if FDI is largely of the horizontal variety, it may not necessarily be hindered more than FPI by greater distance. Second, even if FDI were more of the vertical variety, the foregoing logic probably only holds for Greenfield investments. M\&As and FPI are essentially similar types of investments (keeping in mind the $10 \%$ threshold), and should therefore be impacted more or less equally.

While we do not have data that allows us to distinguish between horizontal and vertical FDI, we do have data on total FDI, FDI in the form of M\&A and FPI. Thus the hypotheses we set out are as follows: In general, FDI ought to be relatively more hindered by greater distance than FPI (Hypothesis 1). Other things equal, FDI in the form of M\&As should be less impacted by distance than total FDI as it is primarily a financial transaction (Hypothesis 2). Since M\&A and FPI are broadly similar types of investments, distance ought not to have any discernible difference between the two (Hypothesis 3). Of course, one could argue that large differences in ownership stakes (e.g. over 50\% and less than $5 \%$ for instance) do make a difference (ownership versus control) and greater distance could negatively impact the extent of ownership stake (home bias). As against this, based on the Goldstein and Razin (2006) argument, without sunk costs, investors would prefer more M\&A if it implies greater control (which includes Greenfield investments). ${ }^{10}$

\section{Model and Data Sources}

\section{A. Gravity model}

We follow the basic gravity model which has become the workhorse model for capital flows. Head and Ries (2008) offer a theoretical basis for a gravity model of cross-border M\&As, while Courdacier and Martin (2006) and Okawa and van Wincoop (2010) do so for financial assets. The baseline specifications to be estimated are outlined below:

\footnotetext{
${ }^{10} \mathrm{An}$ anonymous referee correctly noted that "(f)oreign investors may acquire domestic firms for two reasons: a) diversication or b) control. Typically, investment for the purpose of control would involve a larger stake in the target. And the large exposure in a given firm (or by extension) country surely is harder to liquidate and creates a sunk cost." This is an important point. However, unfortunately we do not have access to the data on equity stakes on M\&A so cannot differentiate M\&As and FPIs based on equity stakes. This is an area of importance for future research - are there certain thresholds that matter in determining control $-10 \%, 20 \%$ etc?
} 


$$
\begin{array}{r}
\ln (F D I / F P I)_{i j t}=\alpha_{0}+\alpha_{1} \ln \left(P O P_{j t}\right)+\alpha_{2} \ln \left(P O P_{i t}\right)+\alpha_{3} \ln \left(G D P P C_{j t}\right)+ \\
\alpha_{4} \ln \left(G D P P C_{i t}\right)+\alpha_{5} \ln \left(D I S T_{i j}\right)+\alpha_{6} \ln \left(X_{i j t}\right)+u_{t}+v_{i j t} \\
\ln (M A / F D I)_{i j t}=\beta_{0}+\beta_{1} \ln \left(P O P_{j t}\right)+\beta_{2} \ln \left(P O P_{i t}\right)+\beta_{3} \ln \left(G D P P C_{j t}\right)+ \\
\beta_{4} \ln \left(G D P P C_{i t}\right)+\beta_{5} \ln \left(D I S T_{i j}\right)+\beta_{6} \ln \left(X_{i j t}\right)+u_{t}+v_{i j t} \\
\ln \left(M A / F P I_{i j t}=\right. \\
\gamma_{0}+\gamma_{1} \ln \left(P O P_{j t}\right)+\gamma_{2} \ln \left(P O P_{i t}\right)+\gamma_{3} \ln \left(G D P P C_{j t}\right)+ \\
\gamma_{4} \ln \left(G D P P C_{i t}\right)+\gamma_{5} \ln \left(D I S T_{i j}\right)+\gamma_{6} \ln \left(X_{i j t}\right)+u_{t}+v_{i j t}
\end{array}
$$

where: $\mathrm{FDI}_{\mathrm{ijt}}, \mathrm{FPI}_{\mathrm{ijt}}$ and $\mathrm{MA}_{\mathrm{ijt}}$ are the total (dollar) values of FDI, FPI and M\&A deals, respectively from source country (i) to host country (j) in time (t); $\mathrm{GDP}_{\text {it }}$ and GDP $_{\mathrm{jt}}$ are nominal GDPs in US dollar for the source country (i) and the host country (j) in time (t); DIST $T_{i j}$ is the geographical distance between host and source countries; $\mathrm{X}_{\mathrm{ijt}}$ is a set of controls. The basic controls we use are contiguity and two measures of enthnolinguistic ties, viz. common language, and common colonial links. We then augment the model with a set of other controls, viz. real exchange rate source per host (rise implies depreciation of host country currency), market capitalization as a share of GDP in the source and host, capital account openness in the source and host and risk premium in the host and source. $u_{t}$ denotes the unobservable time effects (we use year dummies); and $v_{\mathrm{ijt}}$ is a nuisance term. We take logs of the ratios to reduce the impact of extreme values.

The focus of our attention is the distance elasticity. Based on the hypotheses outlined previously, we expect $\alpha_{5}<0$, i.e. the FDI-to-FPI ratio should decline with greater distance. However, the caveats noted above really make this an empirical question. We expect $\beta_{5}>0$ as the greater the distance the more likely any FDI will take the form of M\&A rather than the establishment of a Greenfield entity (given the general uncertainties and sunk costs). As such, the MA-to-FDI ratio should rise with distance. Insofar as M\&A and FPI (equity) are broadly similar types of transactions we expect $\gamma_{5} \approx 0$ (suggesting marginal differences in ownership thresholds or that ownership thresholds do not matter).

\section{B. Data sources}

While the hypotheses are easily laid out, there are practical problems with the data. The FDI data are based on UNCTAD FDI/TNC via the Economic Intelligence Unit's World Investment Service (EIU-WIS) database. While the FDI data are from 
national sources, they are not divided into M\&A versus Greenfield investments. ${ }^{11}$ In fact no database we know of collects Greenfield investments across countries. However, a few commercial entities keep track of domestic and cross-border M\&A activities such as Bloomberg, Thomson Financial Securities Data, ISI Emerging Market, and Bureau Van Dijk. For our study, we use the Bureau Van Dijk M\&A database, also called "Zephyr". Zephyr is a fairly new M\&A database and has extensive global coverage. The practical benefit of using this data is that it is available via the EIU-WIS. ${ }^{12}$ The data collected by Zephyr involves any M\&A with over $2 \%$ equity. ${ }^{13}$ However, the Zephyr data available via the EIU-WIS conform to the $10 \%$ threshold to be considered FDI (rather than portfolio flows) and is therefore preferable to other sources. ${ }^{14}$

While we have bilateral M\&A data, the two (M\&A and Greenfield investments) are not always directly comparable and thus we cannot subtract it from the FDI data to come up with Greenfield investments. This is so for at least three reasons. One, M\&A data, unlike the FDI data, do not include reinvested earnings and other components (such as intracompany lending) or divestment (also see Zhan, 2006). Two, the M\&A data are based on actual ownership of companies as opposed to the flow of funds. This is an important point. Since the FDI data are based on actual flows of funds, while offshore financial centers (OFCs) and other tax havens show up as important sources and destinations of funds in this data, they do not show up as major players in the M\&A data which deals with actual ownership of the purchaser. ${ }^{15}$ Unfortunately there is nothing we can do about these differences. However, as long as there is no systematic change in behavior over time, since we are taking ratios of the two assets, the results should not be affected much. Three, while FDI data are captured when the capital flows actually takes place, the M\&A data is based on

\footnotetext{
${ }^{11}$ See UNCTAD (2006, pp.15-21) for a discussion of Greenfield versus M\&As.

${ }^{12}$ See https://zephyr.bvdep.com/Zephyr/.

${ }^{13}$ According to Zephyr, "(w)hen the bidder is an investment trust or pension fund, then the threshold is raised to $5 \%$." The various private sector companies that collect M\&A data do not appear to use standardized methodologies or definitions making it tricky to compare across databases.

${ }^{14}$ Others such as Di Giovanni (2005), Coeurdacier et al. (2009) and Wong (2008) use the Thomson Financial database. None of these papers seem to heed the $10 \%$ ownership threshold.

${ }^{15} \mathrm{~A}$ significant portion of FDI to the region is from OFCs such as the British Virgin islands, Bermuda, Cayman islands, Mauritius, and Western Samoa (see Hattari and Rajan, 2008, 2009a and Lane and Milesi-Ferretti, 2010). Apart from transhipping, there is also the problem of roundtripping (eg. Hong Kong-China). Also see Gopalan and Rajan (2010) for a discussion of this issue in the context of inflows to and outflows of FDI from India. In relation to this, many commercial enterprises include M\&A deals between foreign affiliates and firms based in the same host economy. These are not a part of balance of payments statistics.
} 
when the deal is actually done. ${ }^{16}$ On average, the ratio of MA-to-FDI is around 0.3 which is broadly consistent with the UNCTAD data (Figure 1) of 0.4. However, for reasons noted above, in many instances we could have a ratio greater than 1 .

With regard to FPI equity investments, the data are sourced from the IMF's Coordinated Portfolio Investment Survey (CPIS).${ }^{17}$ This data geographically breaks down securities holdings in equities (less than 10\%) and bonds by residence of issuers. The data are gathered in a manner consistent with the BoP definition and based on flows of funds. We focus here on portfolio equity. Since 2001, the CPIS has been undertaken on an annual basis involving 74 participating economies (China as a source is a notable omission). IMF-CPIS equity data refers to end of year numbers (i.e. stocks) or positions rather than flows, while the FDI and M\&A data are based on flows. We therefore modified the data from stocks to flows by taking the difference of time $\mathrm{t}$ with $\mathrm{t}-1$. We understand the approach of converting stocks to flows is not without problems because it does not take into account the valuation effect and exchange rate differences on the day of the transactions. ${ }^{18}$

In the original data, there are 2688 country pairs from 2001 to 2007 (48 sources and 57 hosts). Figures 2a-c shows that most of the bilateral equity flows have been

Figure 1. Ratio of Global M\&A-to-FDI, 1992-2008

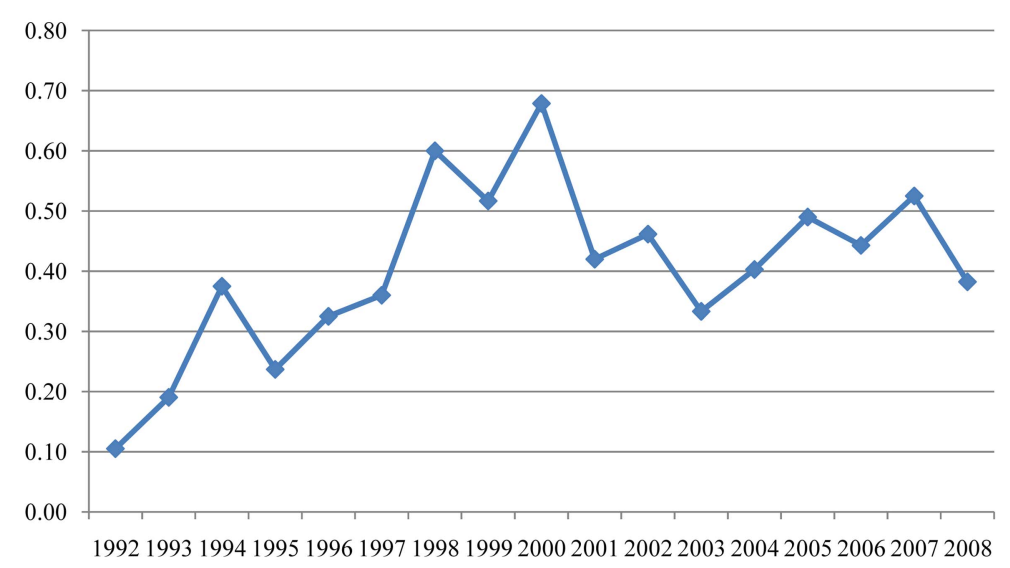

Source: UNCTAD (2008).

\footnotetext{
${ }^{16}$ Some studies use M\&A data when deals are announced as opposed to when they are done.

${ }^{17} \mathrm{See}$ http://www.imf.org/external/np/sta/pi/datarsl.htm.

${ }^{18}$ See Lane and Feretti (2001 and 2008) for discussions on valuation effects on international asset and liability positions of countries. Also note that we undertake estimations using three-year averages in addition to annual data - this should help smooth out valuation changes as well as deal with lumpiness in the data.
} 
Figures 2. Cross-border Equity Flows by Country Pairs
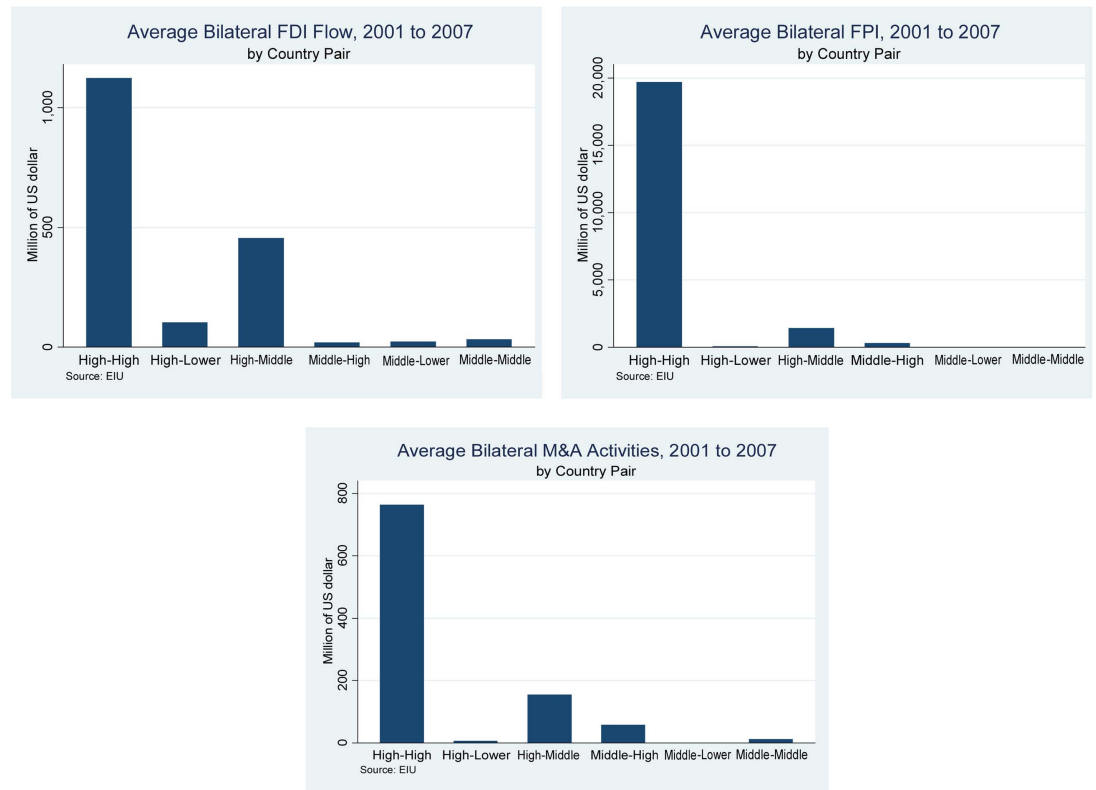

concentrated between high-income economies and from high-income to middleincome economies. Since our interest is in directly comparing the flows of different types across country pairs we need to ensure that we have similar sets of non-zero bilateral pairs across the same time period. ${ }^{19}$ We are left with an unbalanced panel of just under 3300 observations for Regression 1 (FDI/FPI) and about 2500 for Regressions 2 and 3 (mainly because of more limited M\&A observations). ${ }^{20}$ While we have lost a number of observations through this matching process (due to missing observations, empty cells, zeros), the remaining observations are still fairly large compared to others such as Daude and Fratszher (2008) which had 1100 observations in their comparison of FPI and FDI flows.

Data on the independent variables are more straightforward. The source for population and real GDP per capita are from the World Bank's World Development Indicators database. Data for distance, common language, colonial history and

\footnotetext{
${ }^{19}$ Since we are taking the natural log of ratios, in theory we also have to include dependent variables with a ratio of exactly 1 . However, there were no cases like this in our sample.

${ }^{20}$ There are two types of missing observations for FDI and FPI data - empty cells or completely excluded country pairs for some (all) years. In the case of M\&A data there are no empty cells so it is unclear whether these have been entirely excluded or assumed to be zero. It is also unclear what the difference between empty cells, excluded observations and zero observations imply.
} 
contiguity are taken from CEPII. ${ }^{21}$ Data on nominal bilateral exchange rates and consumer price indices (to compute real exchange rate volatility) are from the IMF's International Financial Statistics (IFS). The stock market capitalization data are

Table 2. Summary Statistics

\begin{tabular}{|c|c|c|c|c|}
\hline Variable & Mean & Std. Dev. & Min & Max \\
\hline$\overline{\text { MA (in millions of USD) }}$ & 293.43 & 3179.13 & 0 & 187112.6 \\
\hline FDI (in millions of USD) & 619.53 & 7837.91 & -305502.2 & 394332.1 \\
\hline FPI (in millions of USD) & 7510.94 & 38694.22 & -3.545052 & 1142380 \\
\hline $\begin{array}{l}\text { FDI-to-FPI (both in millions of } \\
\text { USD) }\end{array}$ & 77.94115 & 1862.967 & 0.00000564 & 98138.57 \\
\hline Distance (miles) & 5867.356 & 4842.354 & 59.61723 & 19586.18 \\
\hline $\begin{array}{l}\text { Contiguous (Dummy) } \\
1=\text { Yes; } 0=\text { No }\end{array}$ & 0.088012 & 0.2833556 & 0 & 1 \\
\hline $\begin{array}{l}\text { Common Language (Dummy) } \\
1=\text { Yes; } 0=\text { No }\end{array}$ & 0.129287 & 0.335568 & 0 & 1 \\
\hline $\begin{array}{l}\text { Common Colony (Dummy) } \\
1=\text { Yes; } 0=\text { No }\end{array}$ & 0.060395 & 0.2382525 & 0 & 1 \\
\hline GDP Per capita in USD in $\mathrm{i}$ & 960583.3 & 3277396 & 1118.199 & 19700000 \\
\hline GDP Per capita in USD in $\mathrm{j}$ & 835190.2 & 2885204 & 1118.199 & 19700000 \\
\hline Population in i (billions) & 58.94416 & 105.0394 & 3.917 & 1164.95 \\
\hline Population in $\mathrm{j}$ (billions) & 128.8293 & 288.8624 & 3.917 & 1321.29 \\
\hline $\begin{array}{l}\text { Real exchange rate of } \mathrm{i} \text { w.r.t. } \mathrm{j} \\
\text { (deflated by } \mathrm{CPI} \text { ) }\end{array}$ & 467.2422 & 2899.105 & 0.0000829 & 33727.56 \\
\hline $\begin{array}{l}\text { Market capitalization of listed } \\
\text { companies in } \mathrm{i}(\% \text { of GDP) }\end{array}$ & 104.5639 & 77.00996 & 0 & 561.439 \\
\hline $\begin{array}{l}\text { Market capitalization of listed } \\
\text { companies in i ( } \% \text { of GDP) }\end{array}$ & 78.60439 & 66.33939 & 0 & 561.439 \\
\hline $\begin{array}{l}\text { Financial openness in i (Index) } \\
100=\text { Max } \\
0=\text { Min }\end{array}$ & 2.012267 & 0.9244169 & -1.13058 & 2.531836 \\
\hline $\begin{array}{l}\text { Financial openness in } \mathrm{j} \text { (Index) } \\
100=\text { Max } \\
0=\text { Min }\end{array}$ & 1.393313 & 1.340928 & -1.13058 & 2.531836 \\
\hline $\begin{array}{l}\text { Risk premium on lending in } \mathrm{i} \\
\text { (prime rate minus treasury bill } \\
\text { rate, } \% \text { ) }\end{array}$ & 2.035979 & 4.770575 & -0.03417 & 44.97834 \\
\hline $\begin{array}{l}\text { Risk premium on lending in } \mathrm{j} \\
\text { (prime rate minus treasury bill } \\
\text { rate, } \% \text { ) }\end{array}$ & 3.018163 & 7.629541 & -0.03417 & 44.97834 \\
\hline
\end{tabular}

Source: Authors.

${ }^{21}$ For more information, see http://www.cepii.fr/distance/noticedist_en.pdf. 
taken from Standard \& Poor's. For capital account openness (kaopen), we used the well-known index developed by Chinn and Ito (2002). The index is based on four binary dummy variables, viz. does the country have multiple exchange rates, current account restrictions, capital account restrictions, and requirements of the surrender of export proceeds (as reported in the IMF's Annual Report on Exchange Arrangements and Exchange Restrictions (AREAER)). Risk premium is defined as the prime lending rate minus Treasury bill rate $(\%)$ and the data are from

Table 3. Source and Host Countries

\begin{tabular}{|c|c|c|c|}
\hline Source Countries & & & \\
\hline Argentina & Greece & Pakistan & United Kingdom \\
\hline Australia & Hong Kong & Philippines & United States \\
\hline Austria & Hungary & Poland & Venezuela \\
\hline Belgium & India & Portugal & \\
\hline Brazil & Indonesia & Romania & \\
\hline Bulgaria & Ireland & Russia & \\
\hline Canada & Israel & Singapore & \\
\hline Chile & Italy & Slovakia & \\
\hline Colombia & Japan & South Africa & \\
\hline Czech Republic & Korea & Spain & \\
\hline Denmark & Malaysia & Sweden & \\
\hline Egypt & Mexico & Switzerland & \\
\hline Finland & Netherlands & Thailand & \\
\hline France & New Zealand & Turkey & \\
\hline Germany & Norway & Ukraine & \\
\hline \multicolumn{4}{|l|}{ Host Countries } \\
\hline Argentina & France & Mexico & South Africa \\
\hline Australia & Germany & Netherlands & Spain \\
\hline Austria & Greece & New Zealand & Sri Lanka \\
\hline Belgium & Hong Kong & Nigeria & Sweden \\
\hline Brazil & Hungary & Norway & Switzerland \\
\hline Bulgaria & India & Pakistan & Thailand \\
\hline Canada & Indonesia & Peru & Turkey \\
\hline Chile & Iran & Philippines & Ukraine \\
\hline China & Ireland & Poland & United Kingdom \\
\hline Colombia & Israel & Portugal & United States \\
\hline Czech Republic & Italy & Romania & Venezuela \\
\hline Denmark & Japan & Russia & Vietnam \\
\hline Ecuador & Kazakhstan & Saudi Arabia & \\
\hline Egypt & Korea & Singapore & \\
\hline Finland & Malaysia & Slovakia & \\
\hline
\end{tabular}

Source: Authors. 
Datastream. Table 2 provides the summary statistics of the variables used in the three regressions, while Table 3 outlines the countries in the sample.

\section{Empirical Results}

Before undertaking the estimation on the ratios, it might be useful to estimate with dependent variables of $\ln (\mathrm{FDI}), \ln (\mathrm{FPI})$ and $\ln (\mathrm{MA})$. The results are shown in Table 4. The results indicate that the distance elasticity is negative, similar to the existing literature on capital flows using a gravity equation. What we are interested in is the relative impact of distance on types of (equity) capital flows. We have three sets of results. First we start with the baseline Fixed effects OLS estimation. Second, we re-estimate the data using three-year averages to take into account possible lumpiness in the annualized data. Third, we augment the model with additional controls.

Table 4. Baseline Gravity Model

\begin{tabular}{cccc}
\hline \multirow{2}{*}{ Dependent Variable } & $\begin{array}{c}\text { Fixed Effects OLS } \\
\text { Regression (a) }\end{array}$ & $\begin{array}{c}\text { Fixed Effects OLS } \\
\text { Regression (b) }\end{array}$ & $\begin{array}{c}\text { Fixed Effects OLS } \\
\text { Regression (c) }\end{array}$ \\
& FDI & FPI & MA \\
\hline \multirow{2}{*}{ Constant } & $0.909^{* *}$ & $-1.881^{* * *}$ & 0.916 \\
$\ln$ (Population i) & $0.692^{* * *}$ & $(0.385)$ & $(0.643)$ \\
& $(0.025)$ & $0.714^{* * *}$ & $0.531^{* * *}$ \\
$\ln$ (Population j) & $0.621^{* * *}$ & $(0.022)$ & $(0.029)$ \\
$\ln ($ GDP per capita i) & $(0.022)$ & $0.747^{* * *}$ & $0.457^{* * *}$ \\
& $-0.027^{*}$ & $(0.020)$ & $(0.029)$ \\
$\ln ($ GDP per capita j) & $(0.016)$ & $-0.054 * * *$ & $-0.082^{* * *}$ \\
& $0.050^{* * *}$ & $(0.014)$ & $(0.025)$ \\
In distance & $(0.015)$ & $-0.065^{* * *}$ & $-0.033^{*}$ \\
& $\mathbf{- 0 . 7 7 3 * * *}$ & $(0.012)$ & $(0.020)$ \\
Contiguity & $\mathbf{( 0 . 0 3 4 )}$ & $\mathbf{- 0 . 4 9 1 * * *}$ & $\mathbf{- 0 . 3 3 0 * * *}$ \\
& $0.205^{*}$ & $\mathbf{( 0 . 0 2 6 )}$ & $\mathbf{( 0 . 0 4 2 )}$ \\
Common language & $(0.118)$ & $0.734 * * *$ & $0.635^{* * *}$ \\
& $1.315^{* * *}$ & $(0.110)$ & $(0.139)$ \\
Colony & $(0.101)$ & $1.410^{* * *}$ & $0.536^{* * *}$ \\
Observations & $0.568^{* * *}$ & $(0.075)$ & $(0.102)$ \\
R Squared & $(0.126)$ & $0.327^{* * *}$ & $0.613^{* * *}$ \\
& 5,974 & $(0.119)$ & $(0.134)$ \\
& 0.412 & 12,026 & 3,877 \\
& & 0.488 & 0.192 \\
\hline
\end{tabular}




\section{A. Baseline results: Fixed effects OLS}

Table 5 summarizes the regression results on the ratios (Regressions a-c) using host and source Fixed effects OLS. Recall that the coefficient of interest is the distance elasticities. Focusing on column $2, \alpha_{5}$ is negative $(-0.35)$ and statistically significant. Thus, as distance rises, the FDI-to-FPI ratio declines, implying that FDI is deterred more than FPI. This is also consistent with the finding by Daude and Fratzscher (2008). We know that, in general, economic masses (proxied here by populations and per capita GDP) tend to increase all types of capital flows between countries, but do they do so proportionately? We find that the richer the host and source countries the greater the ratio, implying that FDI increases relatively more than FPI, though the economic significance of these are rather small. In addition, the more populous the source country the greater is the ratio and the more populous the host, the lower the ratio. Common language appears to attract relatively more FDI

Table 5. Annual Baseline Gravity Model

\begin{tabular}{|c|c|c|c|}
\hline Dependent Variable & $\begin{array}{c}\text { Fixed Effects OLS } \\
\text { Regression (a) } \\
\text { FDI/FPI }\end{array}$ & $\begin{array}{c}\text { Fixed Effects OLS } \\
\text { Regression (b) } \\
\text { MA/FDI }\end{array}$ & $\begin{array}{c}\text { Fixed Effects OLS } \\
\text { Regression (c) } \\
\text { MA/FPI }\end{array}$ \\
\hline Constant & $\begin{array}{c}4.725 * * * \\
(0.643)\end{array}$ & $\begin{array}{c}-1.175 \\
(0.848)\end{array}$ & $\begin{array}{c}2.546^{* *} \\
(1.136)\end{array}$ \\
\hline $\ln ($ Population i) & $\begin{array}{c}0.152 * * * \\
(0.033)\end{array}$ & $\begin{array}{c}-0.030 \\
(0.038)\end{array}$ & $\begin{array}{l}-0.018 \\
(0.042)\end{array}$ \\
\hline $\ln ($ Population j) & $\begin{array}{c}-0.147 * * * \\
(0.035)\end{array}$ & $\begin{array}{c}0.011 \\
(0.036)\end{array}$ & $\begin{array}{c}-0.161 * * * \\
(0.040)\end{array}$ \\
\hline In (GDP per capita i) & $\begin{array}{c}0.057 * * \\
(0.024)\end{array}$ & $\begin{array}{c}-0.134 * * * \\
(0.029)\end{array}$ & $\begin{array}{c}-0.098 * * * \\
(0.036)\end{array}$ \\
\hline ln (GDP per capita j) & $\begin{array}{l}0.037^{*} \\
(0.022)\end{array}$ & $\begin{array}{c}-0.035 \\
(0.026)\end{array}$ & $\begin{array}{l}-0.016 \\
(0.028)\end{array}$ \\
\hline In distance & $\begin{array}{c}-0.348 * * * \\
(0.046)\end{array}$ & $\begin{array}{c}0.210 * * * \\
(0.057)\end{array}$ & $\begin{array}{c}0.069 \\
(0.059)\end{array}$ \\
\hline Contiguity & $\begin{array}{c}-0.444 * * * \\
(0.159)\end{array}$ & $\begin{array}{c}0.181 \\
(0.169)\end{array}$ & $\begin{array}{l}0.378^{*} \\
(0.195)\end{array}$ \\
\hline Common language & $\begin{array}{c}0.330 * * \\
(0.133)\end{array}$ & $\begin{array}{c}0.103 \\
(0.139)\end{array}$ & $\begin{array}{c}-0.107 \\
(0.141)\end{array}$ \\
\hline Colony & $\begin{array}{c}0.213 \\
(0.165)\end{array}$ & $\begin{array}{c}0.061 \\
(0.160)\end{array}$ & $\begin{array}{c}0.270 \\
(0.193)\end{array}$ \\
\hline Observations & 3,295 & 2,449 & 2,519 \\
\hline R Squared & 0.136 & 0.044 & 0.142 \\
\hline
\end{tabular}

Notes: Robust standard error in parentheses; $i$ is source country and $\mathrm{j}$ is host country.

$* * *$ Significant at $1 \%$ level; **Significant at $5 \%$ level; ${ }^{*}$ Significant at $10 \%$ level. 
than FPI, while a common border appears to attract relatively more FPI compared to FDI. While the finding of common language is clear-cut (i.e. common language lowers costs of doing business), the finding of common border appears counterintuitive at first glance. However, if relatively more of FDI flows between neighbors is of the horizontal variety then it is possible that firms choose to service the neighboring market via exports rather than FDI, implying that a common border reduces FDI compared to FPI. ${ }^{22}$

Referring to column 3 of Table $5, \beta_{5}$ is positive $(0.21)$, implying that the greater the distance the more likely that any FDI will be in the form of M\&A rather than by establishing a Greenfield entity. This is consistent with our prior. All the other variables are statistically insignificant with the exception of per capita GDP in the source country which enters with a negative sign. This could imply that the richer the source country the more likely that FDI takes the form of Greenfield rather than M\&A.

Referring to column 4 of Table $5, \gamma_{5}$ is close to zero and statistically insignificant, suggesting we cannot reject the null that the distance elasticity is statistically different from 0 . This is consistent with our prior that the M\&A and FPI are essentially similar types of transactions and ought to react the same way to distance. The lack of statistical significance of either of the two ethnolinguistic ratios further fortifies this conclusion. The only other strongly statistically significant terms across both estimations are populations in the host country and GDP per capita in the source country - the larger the host and the richer the source the greater the extent of FPI flows vis-à-vis M\&A flows.

\section{B. Baseline model: Three-year average fixed effect OLS}

Given the lumpiness in the annual flows data, we re-estimate the regressions using three-year averages (Table 6). Comparison of Tables 5 and 6 reveals that the results are highly robust. We focus first on the FDI-to-FPI ratio. The distance elasticity for the three-year average estimation is -0.34 compared to -0.35 using annual data. Both are statistically significant. All other results remain more or less unaffected. In the case of the MA-to-FDI ratio, the elasticities for the annual and three-year averages are also close to each other ( 0.21 for annual and 0.25 for three year averages), and both are statistically significant. Similarly in the case of the MA-toFPI ratio, the corresponding distance elasticity between the annual and three-year

\footnotetext{
${ }^{22}$ Daude and Fratzscher (2008) also find that FDI is more sensitive (positively) to common language than is FPI equity stock though they do not test for common border.
} 
Table 6. Three Year Averages Baseline Gravity Model

\begin{tabular}{|c|c|c|c|}
\hline Dependent Variable & $\begin{array}{c}\text { Fixed Effects OLS } \\
\text { Regression (a) } \\
\text { FDI/FPI }\end{array}$ & $\begin{array}{c}\text { Fixed Effects OLS } \\
\text { Regression (b) } \\
\text { MA/FDI }\end{array}$ & $\begin{array}{c}\text { Fixed Effects OLS } \\
\text { Regression (c) } \\
\text { MA/FPI }\end{array}$ \\
\hline Constant & $\begin{array}{c}4.006 * * * \\
(0.733)\end{array}$ & $\begin{array}{c}-0.322 \\
(0.999)\end{array}$ & $\begin{array}{c}2.694 * * \\
(1.295)\end{array}$ \\
\hline $\ln ($ Population i) & $\begin{array}{c}0.166 * * * \\
(0.039)\end{array}$ & $\begin{array}{l}-0.077 * \\
(0.047)\end{array}$ & $\begin{array}{l}-0.009 \\
(0.051)\end{array}$ \\
\hline $\ln ($ Population j) & $\begin{array}{c}-0.126^{* * *} \\
(0.043)\end{array}$ & $\begin{array}{c}-0.026 \\
(0.044)\end{array}$ & $\begin{array}{c}-0.218 * * * \\
(0.047)\end{array}$ \\
\hline ln (GDP per capita i) & $\begin{array}{c}0.046 \\
(0.029)\end{array}$ & $\begin{array}{c}-0.132 * * * \\
(0.035)\end{array}$ & $\begin{array}{c}-0.115^{* * *} \\
(0.041)\end{array}$ \\
\hline In (GDP per capita j) & $\begin{array}{l}0.047^{*} \\
(0.027)\end{array}$ & $\begin{array}{c}-0.062 * * \\
(0.031)\end{array}$ & $\begin{array}{l}-0.016 \\
(0.032)\end{array}$ \\
\hline In distance & $\begin{array}{c}-0.344 * * * \\
(0.055)\end{array}$ & $\begin{array}{c}0.248 * * * \\
(0.068)\end{array}$ & $\begin{array}{c}0.075 \\
(0.071)\end{array}$ \\
\hline Contiguity & $\begin{array}{l}-0.346^{*} \\
(0.184)\end{array}$ & $\begin{array}{c}0.221 \\
(0.207)\end{array}$ & $\begin{array}{l}0.396^{*} \\
(0.230)\end{array}$ \\
\hline Common language & $\begin{array}{c}0.319 \\
(0.212)\end{array}$ & $\begin{array}{c}0.248 \\
(0.166)\end{array}$ & $\begin{array}{c}0.068 \\
(0.165)\end{array}$ \\
\hline Colony & $\begin{array}{c}0.373 \\
(0.288)\end{array}$ & $\begin{array}{l}-0.020 \\
(0.192)\end{array}$ & $\begin{array}{c}0.447 * \\
(0.233)\end{array}$ \\
\hline Observations & 1,876 & 1,430 & 1,657 \\
\hline R Squared & 0.144 & 0.072 & 0.145 \\
\hline
\end{tabular}

Notes:Robust standard error in parentheses; $i$ is source country and $\mathrm{j}$ is host country.

***Significant at $1 \%$ level; **Significant at $5 \%$ level; *Significant at $10 \%$ level.

averages are very close $(0.069$ as compared 0.075$)$ and neither are statistically significant, suggesting that M\&A and FPI are similar types of assets.

\section{Augmented model}

We go on to augment the model with a further set of economic and financial controls, both to check the robustness of the results as well as to ascertain to what extent other factors may impact the composition of equity flows. Results are summarized in Table 7 (Regression a-c).

We focus first on the FDI-to-FPI ratio. Comparing Columns 2 of Tables 5 and 6, we see that the basic variables remain unchanged. As before, distance and contiguity continue to lead to a shift of investments from FDI to FPI, while common language leads to relatively greater FDI. The only exceptions are the per capita GDPs in the host and source countries which now become statistically insignificant. This is reasonable as we do not have strong priors as to why they should impact the choice 
Table 7. Augmented Gravity Model

\begin{tabular}{|c|c|c|c|}
\hline Dependent Variable & $\begin{array}{c}\text { Fixed Effects OLS } \\
\text { Regression (a) } \\
\text { FDI/FPI }\end{array}$ & $\begin{array}{c}\text { Fixed Effects OLS } \\
\text { Regression (b) } \\
\text { MA/FDI }\end{array}$ & $\begin{array}{c}\text { Fixed Effects OLS } \\
\text { Regression (c) } \\
\text { MA/FPI }\end{array}$ \\
\hline Constant & $\begin{array}{c}5.292 * * * \\
(0.663)\end{array}$ & $\begin{array}{c}-1.677^{*} \\
(0.867)\end{array}$ & $\begin{array}{c}3.001 * * * \\
(1.160)\end{array}$ \\
\hline In (Population i) & $\begin{array}{c}0.111 * * * \\
(0.034)\end{array}$ & $\begin{array}{c}-0.029 \\
(0.038)\end{array}$ & $\begin{array}{c}-0.056 \\
(0.042)\end{array}$ \\
\hline $\ln ($ Population j) & $\begin{array}{c}-0.118^{* * *} \\
(0.034)\end{array}$ & $\begin{array}{c}0.003 \\
(0.037)\end{array}$ & $\begin{array}{c}-0.170 * * * \\
(0.042)\end{array}$ \\
\hline ln (GDP per capita i) & $\begin{array}{c}-0.110 * * \\
(0.050)\end{array}$ & $\begin{array}{c}-0.102 * * \\
(0.050)\end{array}$ & $\begin{array}{c}-0.209^{* * *} \\
(0.071)\end{array}$ \\
\hline ln (GDP per capita j) & $\begin{array}{c}-0.011 \\
(0.046)\end{array}$ & $\begin{array}{c}-0.053 \\
(0.046)\end{array}$ & $\begin{array}{c}0.089 \\
(0.065)\end{array}$ \\
\hline In distance & $\begin{array}{c}-0.360 * * * \\
(0.047)\end{array}$ & $\begin{array}{c}0.229 * * * \\
(0.059)\end{array}$ & $\begin{array}{c}0.072 \\
(0.060)\end{array}$ \\
\hline Contiguity & $\begin{array}{c}-0.440 * * \\
(0.160)\end{array}$ & $\begin{array}{c}0.141 \\
(0.169)\end{array}$ & $\begin{array}{c}0.262 \\
(0.192)\end{array}$ \\
\hline Common language & $\begin{array}{c}0.331 * * \\
(0.136)\end{array}$ & $\begin{array}{c}0.220 \\
(0.144)\end{array}$ & $\begin{array}{c}-0.004 \\
(0.146)\end{array}$ \\
\hline Colony & $\begin{array}{c}0.189 \\
(0.168)\end{array}$ & $\begin{array}{c}0.041 \\
(0.160)\end{array}$ & $\begin{array}{c}0.270 \\
(0.189)\end{array}$ \\
\hline ln (rer_h_s) & $\begin{array}{l}-0.001 \\
(0.043)\end{array}$ & $\begin{array}{c}0.029 \\
(0.043)\end{array}$ & $\begin{array}{l}-0.112 * \\
(0.064)\end{array}$ \\
\hline markcap_GDP_i & $\begin{array}{c}0.000 \\
(0.001)\end{array}$ & $\begin{array}{c}0.001 \\
(0.001)\end{array}$ & $\begin{array}{l}-0.001 \\
(0.001)\end{array}$ \\
\hline markcap_GDP_j & $\begin{array}{c}0.001 \\
(0.001)\end{array}$ & $\begin{array}{c}-0.003 * * * \\
(0.001)\end{array}$ & $\begin{array}{c}-0.002^{* *} \\
(0.001)\end{array}$ \\
\hline kaopen_i & $\begin{array}{c}-0.334 * * * \\
(0.072)\end{array}$ & $\begin{array}{c}-0.166^{*} \\
(0.095)\end{array}$ & $\begin{array}{c}-0.466 * * * \\
(0.108)\end{array}$ \\
\hline kaopen_j & $\begin{array}{c}0.071 \\
(0.055)\end{array}$ & $\begin{array}{c}0.029 \\
(0.060)\end{array}$ & $\begin{array}{l}-0.016 \\
(0.073)\end{array}$ \\
\hline riskprem_i & $\begin{array}{c}0.045 * * * \\
(0.010)\end{array}$ & $\begin{array}{c}0.012 \\
(0.014)\end{array}$ & $\begin{array}{c}0.065 * * * \\
(0.017)\end{array}$ \\
\hline riskprem_j & $\begin{array}{c}-0.028 * * * \\
(0.006)\end{array}$ & $\begin{array}{c}0.000 \\
(0.006)\end{array}$ & $\begin{array}{c}-0.014 \\
(0.009)\end{array}$ \\
\hline Observations & 3,282 & 2,444 & 2,517 \\
\hline R Squared & 0.154 & 0.054 & 0.158 \\
\hline
\end{tabular}

Notes:Robust standard error in parentheses; i is source country and $\mathrm{j}$ is host country.

${ }^{* * *}$ Significant at $1 \%$ level; $* *$ Significant at $5 \%$ level; $*$ Significant at $10 \%$ level.

of undertaking investments in the form of FDI or FPI. With regard to the additional controls, there are two noteworthy findings. Capital account openness in the source tends to lead to greater outflows from that country in the form of FPI compared to 
FDI, while capital account openness in the host has no impact on the composition of flows. What about the case of risk premia? A priori, one would expect that higher risk premium (and/or costlier credit conditions) in the host would tend to lead to greater inflows to that country in the form of FPI rather than FDI. This finding may be related to the issue of uncertainty aversion due to sunk costs. On the other hand, higher risk premium in the source country ought to lead to greater outflows in the form of FDI for the same reason, i.e. the relative risk of incurring sunk costs overseas is lower vis-à-vis the home or source country. The results are consistent with the priors, i.e. source country risk premium is positively associated with the FDI-to-FPI ratio and the host country risk premium is negatively related to it. The real exchange rate does not appear to alter the composition of equity flows.

We consider next the MA-to-FDI ratio. Comparing Columns 3 in Tables 5 and 7, the baseline variables remain almost unchanged with the estimated distance elasticity still at around 0.2 . With regard to the augmented variables, only market capitalization in the host is strongly statistically significant and enters with a negative sign, though it is economically insignificant.

Lastly, we consider the MA-to-FPI ratio. Comparing Columns 4 in Tables 4 and 7, once again the baseline results hold. There does not appear to be any difference in M\&A and FPI at least with regard to distance or the proxies for ethnolinguistic ties. There is some, albeit rather weak statistical evidence that real currency depreciation in the source country leads to greater FPI compared to M\&A. This makes intuitive sense in that the more expensive assets are in the host country, the lower the volume of investment, i.e. smaller percentage share (recall the basic difference between M\&A and FPI is the 10\% threshold). Greater capital account openness in the source appears to favor FPI inflows into the country rather than $M \& A$, though the economic significance of this variable is rather weak. More importantly, larger risk premium in the source leads to greater outflows in the form of M\&A rather than FPI. Combining this with the results previously, it appears that greater risk in the source leads to more M\&A type FDI than FPI outflows and more Greenfield FDI than M\&A type FDI. In other words, with greater risk levels in the source, there is greater willingness to undertake sunk costs overseas, consistent with Goldstein and Razin (2006). Lastly, capital account openness in the source appears to shift investments towards FPI away from M\&A. This is also consistent with the regression (a) in Table 7, where we found that higher capital account openness in the source led to a decline in the FDI-to-FPI ratio. 


\section{Concluding Remarks}

Previous studies have documented the importance of distance as a hindrance to different types of cross-border capital flows. However, almost no attention has been paid to examining whether distance impacts various types of capital flows differently, a gap that this paper has attempted to fill. Given data constraints and in order to maintain focus, the paper limited itself to equity flows - FPI, FDI and M\&As where the hypotheses are also clearer (compared to debt flows). We use a fairly large panel over the period 2000-2007. We find that the data fit our three priors quite well. Broadly, distance affects FDI relatively more than FPI. ${ }^{23}$ Consistent with the fact that FDI in the form of M\&A does not involve as much sunk costs compared to Greenfield and is also much easier to liquidate, we find that distance seems to hinder Greenfield investment relatively more than M\&A. Finally, we find that distance has an almost equal inhibiting impact on FDI in the form of M\&A and FPI, consistent with the fact that they are broadly similar financial transactions with different ownership thresholds. An important area for future research would be to try and ascertain whether the extent of foreign equity stakes matter, i.e. ownership versus control.

\section{Acknowledgments}

Excellent research assistance was provided by Sasidaran Gopalan. A draft of the paper was completed while the second author visited the Hong Kong Institute for Monetary Research (HKIMR). The author gratefully acknowledges the hospitality and support offered by the HKIMR. Excellent comments by an anonymous referee is duly acknowledged. The views expressed in this paper are solely those of the authors.

Received 1 December 2010, Revised 21 March 2011, Accepted 16 May 2011

\footnotetext{
${ }^{23}$ Daude and Fratzscher (2008) find that FDI is more sensitive than FPI to information frictions (proxied by telephone traffic and bilateral trade in newspapers and periodicals) as well as familiarity (proxied by stock of immigrants from the source country in the host).
} 


\section{References}

Acharya, V., H.S. Shin and T. Yorulmazer (2008), "Fire Sale FDI", Mimeo, Princeton University.

Aguiar, M. and G. Gopinath (2005), "Fire-sale Foreign Direct Investment and Liquidity Crises", The Review of Economics and Statistics, 87, 439-452.

Anderson, J.E. and E. van Wincoop (2003), "Gravity with Gravitas: A Solution to the Border Puzzle”, American Economic Review, 93, 170-192.

Albuquerque, R. (2003), "The Composition of International Capital Flows: Risk Sharing Through Foreign Direct Investment", Journal of International Economics, 61, 353-383.

Aviat, A. and N. Courdacier (2007), "The Geography of Trade in Goods and Asset Holdings", Journal of International Economics, 71, 22-51.

Buch, C.M. (2005), "Distance and International Banking", Review of International Economics, 13, 787-804.

Buch, C.M., J. Kleinert and F. Toubal (2004), "The Distance Puzzle: On the Interpretation of the Distance Coefficient in Gravity Equations”, Economics Letters, 83, 293-298.

Bussiere, M. and C. Mulder. (1999), "External Vulnerability in Emerging Market Economies: How High Liquidity Can Offset Weak Fundamentals and the Effects of Contagion?", IMF Working Paper, No.99/88.

Carlson, M. and L. Hernández. (2002), "Determinants and Repercussions of the Composition of Capital Inflows", International Finance Discussion Papers, No.717, Board of Governors of the Federal Reserve System.

Calvo, G.A., L. Leiderman and C.M. Reinhart (1996), "Inflows of Capital to Developing Countries in the 1990s", Journal of Economic Perspectives, 10, 123-139.

Chinn, M.D. and H. Ito (2002), "Capital Account Liberalization, Institutions and Financial Development: Cross Country Evidence”, NBER Working Papers, 8967.

Chuhan, P., G. Perez-Quiros and H. Popper. (1996), "International Capital Flows: Do Short-term Investment and Direct Investment Differ?", World Bank Policy Research Working Paper No.1507.

Claessens, S., M. Dooley and A. Warner, A. (1995), "Portfolio Capital Flows: Hot or Cold", World Bank Economic Review, 9, 153-174.

Coe, D.T., A. Subramanian and N.T. Tamirisa. (2007), "The Missing Globalization Puzzle: Evidence of the Declining Importance of Distance", IMF Staff Papers, 54, 34-58.

Courdacier, N. and P. Martin. (2006), "The Geography of Asset Trade and the Euro: Insiders and Outsiders", Journal of Japanese and International Economies, 23, 90113.

Courdacier, N., R. A. De Santis and A. Aviat. (2009), "Cross-border Mergers and Acquisitions: Financial and Institutional Forces", ECB Working Paper No.1018.

Dasgupta, D. and D. Ratha. (2000), "What Factors Appear to Drive Private Capital Flows to Developing Countries and How Does Official Lending Respond?", Policy Research 
Working Paper Series 2392, The World Bank.

Daude, C. and M. Fratzscher. (2008), "The Pecking Order of Cross-border Investment. Research on Global Financial Stability", Journal of International Economics, 74, 94119.

Deardorff, A.V. (1998), "Determinants of Bilateral Trade: Does Gravity Work in a Neoclassical World", In J.A. Frankel (ed.), The Regionalization of the World Economy. University of Chicago Press for NBER, Chicago.

Di Giovanni, J. (2005), "What Drives Capital Flows? The Case of Cross-border Activity and Financial Deepening", Journal of International Economics, 65, 127-149.

Head, K. and J. Ries. (2008), "FDI as an Outcome of the Market for Corporate Control: Theory and Evidence", Journal of International Economics, 74, 2-20.

Helpman, E., M. Melitz and Y. Rubinstein. (2008), "Estimating Trade Flows; Trading Partners and Trading Volumes", Quarterly Journal of Economics, CXXIII, 441-487.

Edison, H. and C. Reinhart. (2001), "Stopping Hot Money: On the Use of Capital Controls During Financial Crises", Journal of Development Economics, 66, 533-553.

Eichengreen, B. and H. Tong. (2007), "Is China's FDI Coming at the Expense of other Countries?", Journal of the Japanese and International Economies, 21, 153-172.

Evenett, S.J. and W. Keller. (2002), "On Theories Explaining the Success of the Gravity Equation”, Journal of Political Economy, 110, 281-316.

Feenstra, R.C., J.R. Markusen and A.K. Rose. (2001), "Using the Gravity Equation to Differentiate among Alternative Theories of Trade", The Canadian Journal of Economics, 34, 431-447.

Flavin, T., M. Hurley and F. Rousseau. (2002), "Explaining Stock Market Correlation: A Gravity Model Approach", The Manchester School, 70, 87-106.

Frankel, J. and A. Rose. (1996), "Currency Crisis in Emerging Markets: Empirical Indicators", Journal of International Economics, 41, 351-368.

Garcia-Herrero, A., P. Wooldridge and T. Doo Yong. (2009), "Why Don’t Asians Invest in Asia?", The Determinants of Cross-border Portfolio Holdings. Asian Economic Papers, 8, 228-256.

Goldstein, I. and A. Razin. (2006), "An information-Based Tradeoff between Foreign Direct Investment and Foreign Portfolio investment", Journal of International Economics, 70, 271-295.

Gopalan, S. and R.S. Rajan. (2010), "India's FDI Flows: Trying to Make Sense of the Numbers", UNESCAP ARTNET Alerts on Emerging Policy Challenges, Issue No 5, January.

Grossman, G. (1996), "Comments on Alan V. Deardorff. Determinants of Bilateral Trade: Does Gravity Work in a Neoclassical World", In J.A. Frankel (ed.), The Regionalization of the World Economy. University of Chicago for NBER, Chicago.

Hattari, R. and R.S. Rajan. (2008), "Sources of FDI Flows to Developing Asia: The Roles of Distance and Time Zones", ADBI Working Paper No.117.

Hattari, R. and R.S. Rajan. (2009a), "Understanding FDI Flows in Developing Asia", Asia Pacific Economic Literature, 23, 73-93. 
Hattari, R. and R.S. Rajan. (2009b), "Cross-Border Mergers and Acquisitions (M\&As) in Developing Asia: The Role of Financial Variables", HKIMR Working Paper No.36/ 2009.

Hausmann, R. and E. Fernández-Arias. (2000), “Is FDI a Safer Form of Financing?”, IADB Working Paper No.416.

Herrero,G., P. Wooldridge and D.Y. Yang. (2009), "Why Don't Asians Invest in Asia? The Determinants of Cross-Border Portfolio Holdings", Asian Economic Papers, 8, 228246.

Huang, R.R. (2006), "Distance and Trade: Disentangling Unfamiliarity Effects and Transport Cost Effects", European Economic Review, 51, 161-181.

IMF (1998), World Economic Outlook 1998. IMF, Washington, DC.

Javorcik, B.S., C. Özden, M. Spatareanu and C. Neagu. (2011), "Migrant Networks and Foreign Direct Investment", Journal of Development Economics, 94, 231-241.

Kirabaeva, K. and A. Razin. (2009), "Composition of Capital Flows", NBER Working Paper No.15599.

Lane, P.R. and G.M. Milesi-Ferretti. (2001), "The External Wealth of Nations: Measures of Foreign Assets and Liabilities for Industrial and Developing Countries", Journal of International Economics, 55, 263-294.

Lane, P.R. and G.M. Milesi-Ferretti. (2008), "International Investment Patterns", The Review of Economics and Statistics, 90, 538-549.

Lane, P.R. and G.M. Milesi-Ferretti. (2010), "Cross-Border Investment in Small International Financial Centers," IMF Working Paper, No.10/38, February.

Lee, J.H. (2008), "Patterns and Determinants of Cross-border Financial Asset Holdings in East Asia”, ADB Working Paper Series on Regional Economic Integration, No.13.

Levchenko, A. and P. Mauro. (2006), "Do Some Forms of Financial Flows Help Protect from Sudden Stops?”, IMF Working Paper No.06/202.

Liu, L.G., K. Chow and U. Li. (2006), "Determinants of Foreign Direct Investment in East Asia: Did China Crowd Out FDI From her Developing East Asian Neigbours?", HKMA Research Memorandum No.17/2006, November.

Loungani, P., A. Mody, and A. Razin. (2002), "The Global Disconnect: The Role of Transactional Distance and Scale Economies in Gravity Equations", Scottish Journal of Political Economy, 18, 526-543.

Markusen, J.R. (1984), "Multinationals, Multi-Plants Economies, and the Gains from Trade", Journal of International Economics, 16, 205-226.

Martin, M.F. (2008), “China's Sovereign Wealth Fund, CRS Report for Congress", January 22.

Martin, P. and H. Rey. (2004), "Financial Super-markets: Size Matters for Asset Trade", Journal of International Economics, 64, 335-361.

Nitithanprapas, E. and T.D. Willett. (2000), "A Currency Crises Model That Works: A Payments Disequilibrium Approach", Mimeo, Claremont, August.

Okawa, Y. and E. Van Wincoop. (2010), "Gravity in International Finance," HKIMR Working Paper, No. 07/2010, April. 
Papaioannou, E. (2009), "What Drives International Bank Flows?: Politics, Institutions and Other Determinants", Journal of Development Economics, 88, 269-281.

Portes, R. and H. Rey. (2005), "The Determinants of Cross-border Equity Flows", Journal of International Economics, 65, 269-296.

Portes, R., H. Rey and Y. Oh. (2001), "Information and Capital Flows: The Determinants of Transactions in Financial Assets", European Economic Review, 45, 783-796.

Rajan, R.S. and R. Hattari. (2009), "What Explains Intra-Asian FDI Flows?: Do Distance and Trade Matter?", Economics Bulletin, 29, 122-128.

Rose, A. and M. Spiegel. (2004), "A Gravity Model of Sovereign Lending: Trade, Default, and Credit", IMF Staff Papers, 51, 50-63.

Santos Silva, J.M.C. and S. Tenreyro. (2006), "Review of Economics and Statistics", 88, 641-658.

Sarno, L. and M. Taylor. (1999), "Hot Money, Accounting Labels and the Permanence of Capital Flows to Developing Countries: An Empirical Investigation", Journal of Development Economics, 59, 337-64.

Stein, E. and C. Daude. (2007), "Longitude Matters: Time Zones and the Location of Foreign Direct Investment", Journal of International Economics, 71, 96-112.

Stewart, J. (2009), “Tobit or Not Tobit?”, IZA Discussion Paper No.4588.

Sula, O. and T.D. Willett. (2006), "Reversibility of Different Types of Capital Flows to Emerging Markets", Emerging Markets Review, 10, 296-310.

Talamo, G.M. (2007), Institutions, FDI and the Gravity Model. Mimeo.

Tong. H. and S.J. Wei. (2009), "The Composition Matters: Capital Inflows and Liquidity Crunch During a Global Economic Crisis", NBER Working Paper, No.15207.

Tong, S.Y. (2005), "Ethnic Networks in FDI and the Impact of Institutional Development", Review of Development Economics 9, 563-580.

UNCTAD (2006), World Investment Report 2006. UN, New York and Geneva.

UNCTAD (2008), World Investment Report 2008. UN, New York and Geneva.

Wei, S.J. (2000), "How Taxing is Corruption on International Investors?" Review of Economics and Statistics, 82, 1-11.

World Bank. (1999), "Global Economic Prospects and the Developing Countries", Oxford University Press, New York.

Wong, W.K. (2008), "Comparing the Fit of the Gravity Model for Different Cross-border Flows", Economic Letters, 99, 474-477.

Zhan, J. (2006), "FDI Statistics: A Critical Review and Policy Implications", World Association of Investment Promotion Agencies (WAIPA), Geneva, October. 